\title{
TAPHONOMY AND ECOLOGY OF DEEP-WATER EDIACARAN ORGANISMS FROM NORTHWESTERN CANADA
}

NARBONNE*, Guy M., Dept. of Geological Sciences, Queen's University, Kingston, Ontario K7L 3N6, Canada; DALRYMPLE, Robert W., Dept. of Geological Sciences, Queen's University, Kingston, Ont. K7L 3N6

Although most occurrences of Ediacaran fossils are from shallow-shelf deposits, taxonomically-similar assemblages have recently been described from a $2.5 \mathrm{~km}$-thick succession of dark mudstones and turbiditic sandstones in the Windermere Supergroup of the Mackenzie Mountains, northwestern Canada. The paleogeographic position (20-40 km seaward of the shelf edge), abundant evidence of mass flow, and the complete absence of in situ shallow-water features imply that deposition took place on a slope considerably below storm wave-base. Ediacaran fossils were not observed in axial trough deposits (lower parts of the Twitya and Sheepbed formations), but megafossils occur sporadically in lower to middle slope deposits higher in the same formations. Megafossils and trace fossils are present in upper slope settings (Blueflower Formation) at the top of the Ediacaran succession. The megafossil assemblage varies stratigraphically, but in all formations is dominated by discoid forms (e.g. Cyclomedusa, Ediacaria, Nimbia); frondose forms and vendomiids are very rare. Megafossils are preserved mainly as positive features on the soles of thin turbidite beds. Most fossiliferous beds begin with the rippled layer of the turbidite $\left(T_{c}\right)$, but a few begin with the graded $\left(T_{a}\right)$ or parallel-laminated $\left(T_{b}\right)$ layer. Consistent orientation and high relief of individuals, evidence of mutual deformation during growth of adjacent organisms, and other taphonomic features imply that virtually all of the taxa represent benthic polypoid and frond-like organisms (not jellyfish). Slump structures occur commonly in the sandstone fill of fossils, suggesting that many of the organisms were buried alive by the turbidite and later decomposed. Other individuals, even on the same bedding plane, exhibit graded to laminated fill identical to that of the overlying turbidite bed, indicating that the depressions on the sea bottom produced by these individuals were empty at the time of turbidite deposition. Escape structures are absent, suggesting that the Ediacaran organisms were not capable of burrowing up through even thin layers of sand.

Ediacaran megafossils are invariably preserved on black, wrinkled surfaces similar to those elsewhere interpreted as microbial mats. Molding of delicate features (including tentacles), preservation of open molds as negative epireliefs, and sedimentological evidence of considerable cohesion of these surfaces relative to the underlying turbiditic muds $\left(\mathrm{T}_{\mathrm{d}, \mathrm{e}}\right)$ supports this interpretation, and suggests that microbial mats were as important in the preservation of these deep-water Ediacara faunas as they were in their shallow-water equivalents. The presence of the wrinkled mats and their associated Ediacaran fossils almost exclusively in the pyritic intervals of the succession suggests that both may have lived under exaerobic conditions in this deep-water setting. 